\title{
Association of severity of COPD with IgE and interleukin-1beta
}

\author{
B. Singh 1 , S. Arora2 ${ }^{2}$ V. Khanna ${ }^{3}$
}

ABSTRACT: Association of severity of COPD with IgE and interleukin-1beta. B. Singh, S. Arora, V. Khanna.

Background. Chronic obstructive pulmonary disease (COPD) is a pulmonary inflammatory disease characterised by airflow limitation. The role of various inflammatory mediators such as interleukin-1beta (IL-1 $\beta$ ) and Immunoglobulin E (IgE) have been implicated in COPD. In present study we aimed to establish if there is an association between the serum levels of IL-1 $\beta$ and IgE and the severity of airway obstruction.

Materials and methods. The study group comprised of 30 non atopic smokers, suffering from COPD and 30 non smoker, healthy controls. Serum levels of IgE and IL-1 $\beta$ were assayed by ELISA in all subjects along with their pulmonary function tests.

Results. Serum IgE and IL-1 $\beta$ levels were significantly raised in COPD patients as compared to healthy controls. IL-1 $\beta$ was negatively correlated with $\mathrm{FEV}_{1}(r=-0.624$, $p=0.003)$ and IgE showed a negative correlation with $\mathrm{FVC}$ $(r=-0.477, p=0.034)$

Conclusion. Our study suggests that in COPD IL-1 $\beta$ and IgE serum levels correlate with clinical aspects of disease severity. We suggest that the production of IgE and IL-1 $\beta$ in the airways of patients with COPD may be related to smoking which affects airway obstruction. Monaldi Arch Chest Dis 2010; 73: 2, 86-87.

Keywords: IgE, IL-1 beta, Cytokines, Pro inflammatory, Smoking, Airways.

1 Department of Biochemistry, GB Pant Hospital,

2 Department of Biochemistry, Lady Hardinge Medical College,

3 Department of Medicine, Health care centre, Government of National Capital Territory, Delhi, India.

Correspondence: Dr. Bhawna Singh, Assistant Professor, Department of Biochemistry, Room no. 418, G B Pant Hospital, New Delhi, India; e-mail: bhawna172@gmail.com

Chronic obstructive pulmonary disease (COPD) results from airway inflammation involving multiple inflammatory mediators and tissue damage. It has also been suggested that elevated $\operatorname{IgE}$ play a role in chronic airway obstruction [1]. The association of IL-1 $\beta$ gene with COPD has been studied in recent times and its polymorphisms at the position -511 have been found to be associated with susceptibility to COPD [2].

Persistent smoking-induced inflammation plays an important role in the pathogenesis of COPD by increasing macrophage and T lymphocyte in bronchial wall and influx of neutrophils into the airway lumen; however only a fraction of smokers end up in developing COPD [3].

IgE immune complexes stimulate FceRII and mediate expression and release of IL- $1 \beta$ by mononuclear cells [4]. Serum IgE levels are often increased in smokers [5] which may induce IL-1 $\beta$ expression in monocytes. The present study was undertaken to investigate the association and potential activity of serum IL-1 $\beta$ and IgE levels in COPD.

The test group consisted of 30 current smokers (age: 48 to $66 \mathrm{yrs}$ ) with moderate to severe COPD. All the patients had a history of smoking an average of 19 pack/year (10-40 pack/ year) for 30 years (10-40 years). The diagnosis of COPD was made using the Global Initiative for Chronic Obstructive Pulmonary Disease (GOLD) standard [6]. Thirty healthy and non-smoker volunteers constituted the control group. Spirometry, routine blood investigations, chest X-rays, stool test for parasites and skin prick test (SPT) with 10 common allergen extracts (Cockroach male, Cockroach female, Housefly, Moth, Butterfly, House dust, House Dust Mite, Aspergillus, Cynodon, Chenopodium) were performed on all patients. The Student's $t$ or MannWhitney $U$ test was used to evaluate the differences in continuous variables. Pearson's rank correlation was applied to assess the association between various pulmonary function tests and immunological parameters.

In the control group, the IL-1 $\beta$ level was $2.11 \pm 0.16 \mathrm{pg} / \mathrm{ml}$ (range: $0.39-2.97 \mathrm{pg} / \mathrm{ml}$ ), which was significantly lower than COPD patients (3.14 \pm 0.07 , range: $2.8-4.59 \mathrm{pg} / \mathrm{ml}, p<0.05)$. The mean serum IgE levels were $41.9 \pm 3.58 \mathrm{IU} / \mathrm{ml}$ (range: $28-65 \mathrm{IU} / \mathrm{ml}$ ) in controls and $112.3 \pm 4.22$ $\mathrm{IU} / \mathrm{ml}$ (range: $78-169 \mathrm{IU} / \mathrm{ml}$ ) in COPD patients $(p<0.001)$. Stool test was found to be negative for parasitic infestation and eosinophil count was in the normal range in both the groups.

The $\mathrm{FEV}_{1}$ percent of predicted in controls was 80 to $100 \%$ (mean $88.8 \% \pm 0.95$ ) while in COPD patients it ranged between 17 to $66 \%(39.8 \% \pm 2.61)$. FVC percent of predicted ranged from 85 to $103 \%$ $(90.5 \% \pm 1.18)$ in controls and 51 to $78 \%(69.5 \pm 1.53)$ in COPD patients. Mean $\mathrm{FEV}_{1} / \mathrm{FVC}$ ratio in controls was $0.84 \pm .01$ and $0.43 \pm 0.01$ in COPD patients. Both $\mathrm{FEV}_{1}$ and $\mathrm{FEV}_{1} / \mathrm{FVC}$ were significantly lower in cases than the control group $(p<0.001)$.

Table 1 depicts the correlations between $\operatorname{IgE}$, IL-1 $\beta$, smoking pack years and $\mathrm{FEV}_{1}, \mathrm{FEV}_{1} / \mathrm{FVC}$ and FVC. A negative correlation was observed be- 
Table 1. - Correlation between serum IL-1 $\beta$, IgE and pulmonary function tests in patients of COPD

\begin{tabular}{lcc}
\hline & \multicolumn{2}{c}{ COPD } \\
\cline { 2 - 3 } & $\mathbf{r}$ & $\mathbf{p}$ \\
\hline IgE vs. IL-1 $\beta$ & 0.210 & 0.374 \\
IgE vs. FVC & $\mathbf{- 0 . 4 7 7}$ & $\mathbf{0 . 0 3 4}$ \\
IgE vs. FEV $1 /$ FVC & 0.252 & 0.284 \\
IL-1 $\beta$ vs. FEV $1 \%$ & $\mathbf{- 0 . 6 2 4}$ & $\mathbf{0 . 0 0 3}$ \\
IL-1 $\beta$ vs. FEV1/FVC & 0.059 & 0.803 \\
Smoking (pack years) vs. IgE & 0.02 & 0.933 \\
Smoking (pack yrs) vs. IL-1 $\beta$ & $\mathbf{0 . 4 6 7}$ & $\mathbf{0 . 0 3 8}$ \\
Smoking (pack yrs) vs. FEV ${ }_{1} \%$ & $\mathbf{- 0 . 4 9 3}$ & $\mathbf{0 . 0 2 7}$ \\
Smoking (pack years) vs. FEV ${ }_{1} /$ FVC & -0.269 & 0.251 \\
\hline
\end{tabular}

tween IL-1 $\beta$ and $\mathrm{FEV}_{1}$ ( $\left.r=-0.624, p=0.003\right)$, though no correlation was observed between IL-1 $\beta$ and $\mathrm{FEV}_{1} / \mathrm{FVC}(r=0.059, p=0.803)$. Serum IgE was observed to have a negative correlation with FVC in COPD patients ( $r=-0.477, p=0.034)$. Smoking pack years depicted significant positive relation with $\mathrm{IL}-1 \beta(r=0.467, p=0.038)$ and inverse with $\mathrm{FEV}_{1}(\mathrm{r}=-0.493, \mathrm{p}=0.027)$ however no correlation was observed with $\mathrm{IgE}$ and $\mathrm{FEV}_{1} / \mathrm{FVC}$.

In smokers, the risk for developing COPD is dose related [6]. Smoking results in a non-specific increase in $\operatorname{IgE}$ as a result of interference with $\operatorname{IgE}$ regulatory mechanisms. Mechanism for IgE production in airways of smokers might be due to tobacco or due to induction of allergenic altered proteins in the airway as seen in isocyanate sensitivity [5] or due to increased B cells in COPD [7]. In the present study, IgE levels were significantly elevated in COPD patients in spite of their non atopic status as confirmed by negative skin prick tests. Renkema et al also demonstrated a higher initial serum IgE level in non atopic COPD patients [8].

The present study demonstrated significantly high levels of IL-1 $\beta$ in serum of the COPD patients as compared to the healthy controls. A few studied previously undertaken have also reported a rise in IL-1 $\beta$ in COPD cases [9]. It can thus be speculated that in COPD, IL- $1 \beta$ expression may be induced in monocytes due to increased IgE levels, which may lead to their increased release in blood, although we could not observe any correlation between both IL-1 $\beta$ and IgE due to the limited sample size.

$\mathrm{FEV}_{1}$ and $\mathrm{FEV}_{1} / \mathrm{FVC}$ ratio aid to identify airflow obstruction where as FVC predicts restrictive pattern of obstruction. In the present study, the subjects who were chronic smokers, suffered from moderate to severe airway obstruction as $\mathrm{FEV}_{1}$ and $\mathrm{FEV}_{1} / \mathrm{FVC}$ were significantly lower. We observed that IgE correlated inversely with FVC whereas IL-1 $\beta$ correlated inversely with $\mathrm{FEV}_{1}$, though neither of them depicted any correlation with the ratio $\mathrm{FEV}_{1} / \mathrm{FVC}$. Several studies show a significant excess decline in $\mathrm{FEV}_{1}$ in smokers over non-smokers, ex-smokers and quitters [10]. In- creased levels of circulating cytokines and acute phase reactants have been seen in the peripheral circulation of patients suffering from COPD, especially during exacerbations. Sapey et al have proved that IL-1 $\beta$ plays critical role in COPD where it was found to correlate significantly with $\mathrm{FEV}_{1}$ suggesting its role in clinical aspects of disease severity [9].

Modulation of various inflammatory mediators may help in combating the clinical outcome of COPD and may have therapeutic implications whereas determination of serum IL- $1 \beta$ levels may help in differentiating COPD from other respiratory disorders such as asthma [11]. The present study has a few limitations. It was cross-sectional, so its ability to infer causality is limited. Population based studies are required to validate the findings. Levels of $\mathrm{IgE}$ and IL-1 $\beta$ in broncho-alveolar lavage would give a better picture of cytokine milieu in COPD instead of serum levels. Despite these limitations, the findings of this study were significant and may provide an insight into the role of $\operatorname{IgE}$ and IL-1 $\beta$ in severity of COPD.

\section{References}

1. Vollmer WM, Buist AS, Johnson LR, McCamant LE, Halonen M. Relationship between serum IgE and crosssectional and longitudinal FEV1 in two cohort studies. Chest 1986; 90: 416-423.

2. Asada M, Yamaya M, Ebihara S, et al. Interleukin-1 $\beta$ Gene Polymorphisms Associated With COPD. Chest 2005; 128: 1072-1073.

3. Saetta M, Turato G, Maestrelli P, Mapp CE, Fabbri LM. Cellular and structural bases of chronic obstructive pulmonary disease. Am J Respir Crit Care Med 2001; 163: 1304-1309.

4. Kips JC, Pauwels RA. Are cytokines responsible for the asthmatic state of the airway? Monaldi Archives for Chest Disease 1996; 51: 223-227.

5. Bernstein IL. Isocyanate-induced pulmonary diseases: a current perspective. J Allerg Clin Immunol 1982; 70: 24-31.

6. Pauwels RA, Buist AS, Calverley PM, Jenkins CR, Hurd SS. Global strategy for the diagnosis, management, and prevention of chronic obstructive pulmonary disease. NHLBI/WHO Global Initiative for Chronic Obstructive Lung Disease (GOLD) Workshop summary. Am J Respir Crit Care Med 2001; 163: 1256-1276.

7. Hogg JC, Chu F, Utokaparch S, et al. The nature of small-airway obstruction in chronic obstructive pulmonary disease. N Engl J Med 2004; 350: 2645-2653.

8. Renkema TEJ, Kerstjens HAM, Schouten JP, Vonk JM, Koëter GH, Postma DS. The importance of serum IgE for level and longitudinal change in airways hyperresponsiveness in COPD. Clin Exp Allergy 1998; 28: 1210-1218.

9. Sapey E, Ahmad A, Bayley D, et al. Imbalances Between Interleukin-1 and Tumor Necrosis Factor Agonists and Antagonists in Stable COPD. J Clin Immunol 2009; 29: 508-516.

10. Pelkonen M, Notkola IL, Tukiainen H, Tervahauta M, Tuomilehto J, Nissinen A. Smoking cessation, decline in pulmonary function and total mortality: a 30-year follow up study among the Finnish cohorts of the Seven Countries Study. Thorax 2001; 56: 703-707.

11. Mahajan B, Vijayan VK, Agarwal MK, Bansal SK. Serum interleukin-1beta as a marker for differentiation of asthma and chronic obstructive pulmonary disease. Biomarkers 2008; 13: 713-727. 